\title{
Saharawi Women - Educators and Promoters of Peace
}

\author{
Monika Ciesielkiewicz (Corresponding author) \\ School of Education, Villanueva-Universidad Complutense Madrid \\ Costa Brava 2, 28034, Madrid, Spain \\ Óscar Garrido Guijarro \\ School of Communication, Villanueva-Universidad Complutense Madrid \\ Costa Brava 2, 28034, Madrid, Spain \\ E-mail: ogarrido@villanueva.edu Tel: 34-91-734-0413
}

Received: May 28, 2017 Accepted: July 23, 2017 Published: September 11, 2017

doi:10.5296/iss.v5i2.11313 URL: http://dx.doi.org/10.5296/iss.v5i2.11313

\begin{abstract}
The purpose of this paper is to explore the role of Saharawi women as educators and promoters of peace. The study includes published research on the topic, as well as two interviews conducted with a Paz Martín Lozano, a Spanish politician who is an expert on Saharawi issues, and Jadiyetu El Mohtar, a Saharawi activist and representative of the National Union of Saharawi Women (UNMS) who was well known by the Spanish media due to the hunger strike that she went on at the Lanzarote Airport in 2009. Despite the unbearable extreme conditions, Saharawi people were able to organize their political, economic and social life in refugee camps in the middle of a desert, mainly thanks to the incredible Saharawi women who educate their children to fight for the liberation of the territory of Western Sahara in a peaceful and non-violent way. They are striving for the recognition of the Saharawi cause at the international level and raising awareness of their right to self-determination through a free and fair referendum. They provide an excellent example for their children and transmit the values of peace, non-violent resistance, and not despairing in the face of difficult circumstances.
\end{abstract}

Keywords: Western Sahara conflict, Saharawi women, Sahrawi women, refugee camps, conflict irresolution 


\section{Introduction}

The Saharawi Arab Democratic Republic (SADR), better known as Western Sahara, is nestled in an arid desert region, with sparse and largely nomadic population. In 1949, the Spanish geologist Manuel Alia Medina discovered phosphate deposits in the territory, and after more than a decade of exploration, the researchers concluded that these constitute the world's largest open-pit phosphate deposit. It is estimated that there are two million tons of ore, with a purity of between seventy and eighty percent, that can be mined for a century and a half before its exhaustion. Since then, the Western Sahara has been called the "Kuwait of phosphate," so we can get an initial idea of the strategic energy reserves and economic interests surrounding all matters relating to its independence. Since the seventies, there have been successive discoveries of mineral wealth in the region: phosphate, uranium, iron, copper, and zinc can be extracted in abundance within its borders. The mining of the Western Sahara's natural resources has generated conflict with visible consequences.

The Western Sahara includes two regions: Sakia el-Hamra (Red Channel) in the north, and Wadi ed Dahab (Rio de Oro) in the South. Sakia el-Hamra is a great river channel with steep overgrown banks, a sandy bed, and about four kilometers in length. El Aaiun, the capital of the territory, is located about twenty kilometers from the coast and on the river channel. For its part, the Rio de Oro has mostly steep banks on which are found Villa Cisneros Bay and Peninsula (Dakhla), Cintra Bay, Cape Barbas, with a lighthouse, and the peninsula of Cape Blanco, with the city of La Güera. (Lemarchand, 2000)

\section{The Current Situation of the SADR}

The SADR is represented by a national liberation movement, the Popular Front for the Liberation of Sakia el-Hamra and Rio de Oro, known as the Polisario Front, whose current mission is to work to end Morocco's occupation and lead the effort to bring about self-determination for the Saharawi people. The Polisario Front was founded on May 10, 1973, in Zouerate, Mauritania, with the first goal of obtaining the territory's independence from Spanish colonial rule. Since 1975, this organization has been based in Tindouf, on Algerian soil. In 1976 the Independent Democratic Arab Republic of Sahara was established.

From 1884 until 1975 the Western Sahara was a Spanish colony. On November 14, 1975, in the same month that saw the famous "Green March" (a Moroccan military operation launched on November 6, 1975, to occupy the territories of the Spanish Sahara), the Madrid Accords were signed, this being an abbreviation of the formal title of The Declaration of Principles between Spain, Morocco, and Mauritania of the Western Sahara. This is a political declaration, to which must be added several secret appendices, economic in nature, which stipulate that Spain would transfer the administration, but not sovereignty, of Western Sahara to a temporary tripartite administration composed of Spain, Morocco, and Mauritania.

Yet the legal validity of this agreement has been challenged by the Secretary-General for Legal Affairs and Legal Counsel of the United Nations, Hans Corell, in an opinion of 29 January 2002, and the UN has never considered Morocco or Mauritania as administrative powers of the Western Sahara, which continues to be included in the UN list of territories awaiting 
decolonization. To this effect one must consider points 5, 6, and 7 of the UN opinion of January 29, 2002, in which the status of Western Sahara is discussed: (Note 1)

5. A Spanish protectorate since 1884, Spanish Sahara was included in 1963 in the list of Non-Self-Governing Territories under Chapter XI of the Charter (A/5514, annex III). Beginning in 1962, Spain as administering Power transmitted technical and statistical information on the Territory under Article 73 e of the Charter of the United Nations. This information was examined by the Special Committee on the Situation with regard to the Implementation of the Declaration on the Granting of Independence to Colonial Countries and Peoples ("the Special Committee"). In a series of General Assembly resolutions on the question of Spanish/Western Sahara, the applicability to the Territory of the Declaration on the Granting of Independence to Colonial Countries and Peoples (General Assembly resolution 1514 (XV)) was reaffirmed.

6. On 14 November 1975, a Declaration of Principles on Western Sahara was concluded in Madrid between Spain, Morocco and Mauritania ("the Madrid Agreement"), whereby the powers and responsibilities of Spain, as the administering Power of the Territory, were transferred to a temporary tripartite administration. The Madrid Agreement did not transfer sovereignty over the Territory, nor did it confer upon any of the signatories the status of an administering Power, a status which Spain alone could not have unilaterally transferred. The transfer of administrative authority over the Territory to Morocco and Mauritania in 1975 did not affect the international status of Western Sahara as a Non-Self-Governing Territory.

7. On 26 February 1976, Spain informed the Secretary-General that as of that date it had terminated its presence in Western Sahara and relinquished its responsibilities over the Territory, thus leaving it in fact under the administration of both Morocco and Mauritania in their respective controlled areas. Following the withdrawal of Mauritania from the Territory in 1979, upon the conclusion of the Mauritano-Sahraoui agreement of 19 August 1979 (S/13503, annex I), Morocco has administered the Territory of Western Sahara alone. Morocco, however, is not listed as the administering Power of the Territory in the United Nations list of Non-SelfGoverning Territories, and has, therefore, not transmitted information on the Territory in accordance with Article 73 of the Charter of the United Nations.

In 1979, after fierce fighting, the Mauritanians renounced any territorial claim over Western Sahara. Morocco to this day, however, occupies most of the territories that were part of the original Spanish colony, and has surrounded them by walls in order to contain the Polisario Front. The consequence of this conflict is that much of the indigenous population remains in exile in Tindouf refugee camps in Algerian territory.

In 1985, the Secretary General of the United Nations began a mission that resulted in "the settlement proposals," accepted on August 30, 1988, by Morocco and the Polisario Front. In 1990, the Security Council approved the full text of the settlement proposals and outlined the plan of the Secretary General for implementation. On April 29, 1991, the Security Council decided to create, in resolution 690, the United Nations Mission for the Referendum in Western Sahara (MINURSO), whose main purpose was the holding of a referendum on self-determination in January 1992. However, the UN postponed the referendum with 
resolution 725 of December 1991. Since then the issue of the referendum remains blocked and the main task of MINURSO is currently limited to monitoring the ceasefire and cessation of hostilities. (Almario, 2012)

\section{The Involvement of Other Countries}

Since the eighties, the UN has intervened, trying to provide a solution to a conflict of more than three decades, and the oldest unresolved conflict in Africa. However, the UN has been unable to reach a final and lasting solution because of the conflicting interests of the parties involved in the conflict of the region. The Western Sahara issue has always been framed by the intervention of different governments seeking to protect their own interests. The governments that have had more relevant roles in the conflict are Morocco, Mauritania, Spain, Algeria, France, and the United States.

Morocco. Since independence in 1956, Morocco has always sought by all means to achieve the construction of the Greater Morocco, covering the whole of Morocco, the Spanish territory of Ceuta and Melilla, Western Sahara, Ifni, part of Algeria, Mauritania and part of Mali. Morocco has guided its policy of expansion into the Western Sahara, and opposed the inclusion of the Western Sahara in the list of territories awaiting decolonization. In the last three decades, Morocco has sought to legitimize its occupation, has blocked the process for holding a referendum, has signed agreements to exploit resources of Western Sahara with other countries, and has strengthened the Moroccan presence in the territory. (Mera, 2007)

Mauritania. This state has been directly involved in the conflict in Western Sahara as one of the three countries, along with Morocco and Spain, who signed the Madrid Accords. Mauritania always relied upon Moroccan military support to maintain control in the part of Sahara it occupied. The Polisario knew that the territories that had once been occupied by Mauritania were the weakest. Despite support by Morocco and France, Mauritania failed to hold firm in its position because the occupation required a great effort and they were not able to deal with attacks by the Polisario Front.

Spain. The various governments of Spain have always dealt with this issue with ambiguity. Although Spain has always wanted to appear neutral, the commitments that link them to Morocco have ultimately caused them to take the side of its southern neighbor. In its position on the conflict, geostrategic and economic interests such as fishing, the significant presence of Spanish companies operating in Morocco, cooperation in the fight against illegal immigration, cooperation against drug trafficking have taken precedence over the moral responsibility to guard the rights of Sahrawis as a colonial power. Moreover, the autonomous Moroccans deepened personal and economic ties, and have very close relationships with the current Head of the Spanish State, His Majesty King Juan Carlos I, and Felipe González, the former socialist Prime Minister of fourteen years.

Algeria. This country is the staunch ally of the Saharawi people. Algeria has always maintained a very strong rivalry with Morocco. The Polisario has received economic and military aid from Algeria, as well as set aside part of its territory, Tindouf, for the Sahrawi people to set up refugee camps. The political support extends to the point that the Sahrawi refugees are allowed 


\section{Macrothink}

to travel with Algerian passports. Morocco considers that Algeria's position reflects the self-interest of achieving an outlet to the Atlantic Ocean.

France. Throughout the conflict, France has proven to be a staunch ally of Morocco and has provided economic, military, and political aid. The country still maintains French economic interests and a strong influence in the Maghreb. France, like the United States, has used its permanent membership in the Security Council of the UN to Morocco's advantage. (Mera, 2007).

United States. Morocco is the main U.S. ally in North Africa. The U.S. government gave the green light to Morocco to carry out the "Green March," and has supported Morocco both financially and logistically. Still, administrations such as that of Bill Clinton, have sought to find a peaceful solution to the conflict.

\section{Expert Insights from the Interviews with Paz Martín Lozano and Jadiyetu EI Mohtar}

While men were at war, women were left alone and had to build the refugee camps on their own. They built houses, schools, and health centers in the middle of nowhere, in the middle of the desert. They had to take charge of everything while struggling to survive extreme conditions. They learned how to live without men. They created administrative and political structures in exile. They organized social, political, and economic life from scratch.

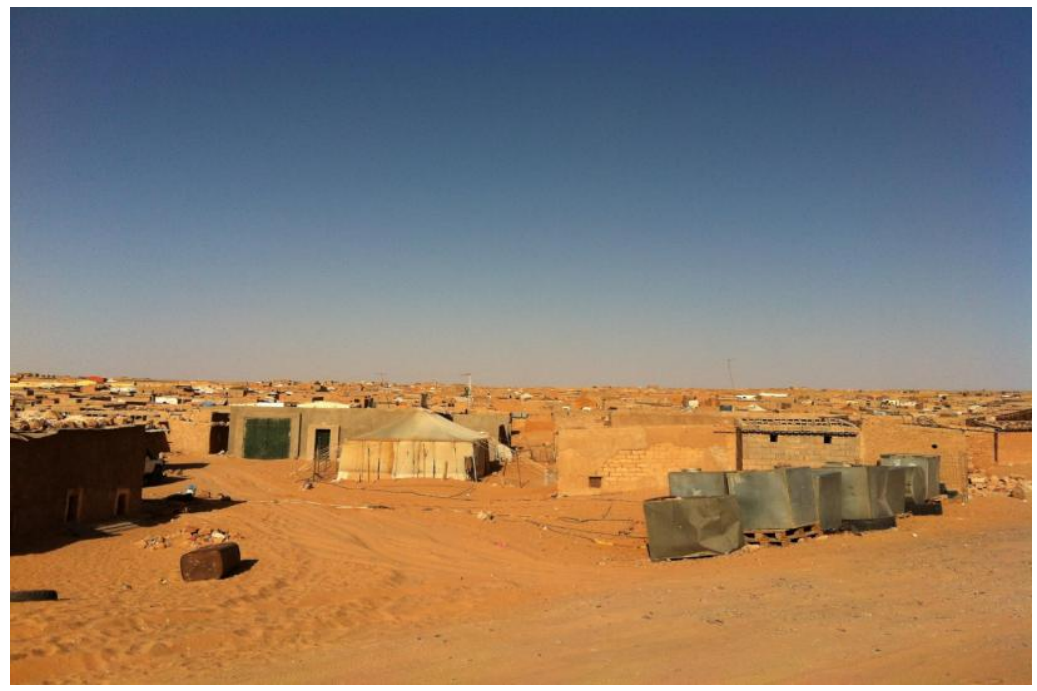

Figure 1. Sahrawi refugee camps

The creation of the refugee camps can be divided into three different phases. During the first, dubbed the survival or wartime phase, civilians created the first settlements in the southern part of Algeria where humanitarian aid was distributed. In the second phase, the settlements kept growing thanks to international aid and volunteers who were coming to the refugee camps from abroad. All the tasks were supervised and run by the National Union of Saharawi Women. The third period is characterized by the strengthening of state structures and platforms, encouraging women's participation in political, economic, and social life, as well as training and education. 


\section{Macrothink}

At the international level, there have been several objectives established, such as striving for recognition of the Saharawi cause, liberation of the territory of Western Sahara, expulsion of the invading army, and the recognition of the Democratic Republic of Sahara.

Refugees have been living in different camps that correspond to the regions in Western Sahara. They have been living on humanitarian aid; however, Saharawi women are very enterprising. They applied for microloans and start their own small businesses. They invested the money in livestock, stockbreeding, trade, sewing, crafts, and vegetable gardens. They even started their own radio and TV stations, in which the videographers, technicians, and other employees are women.

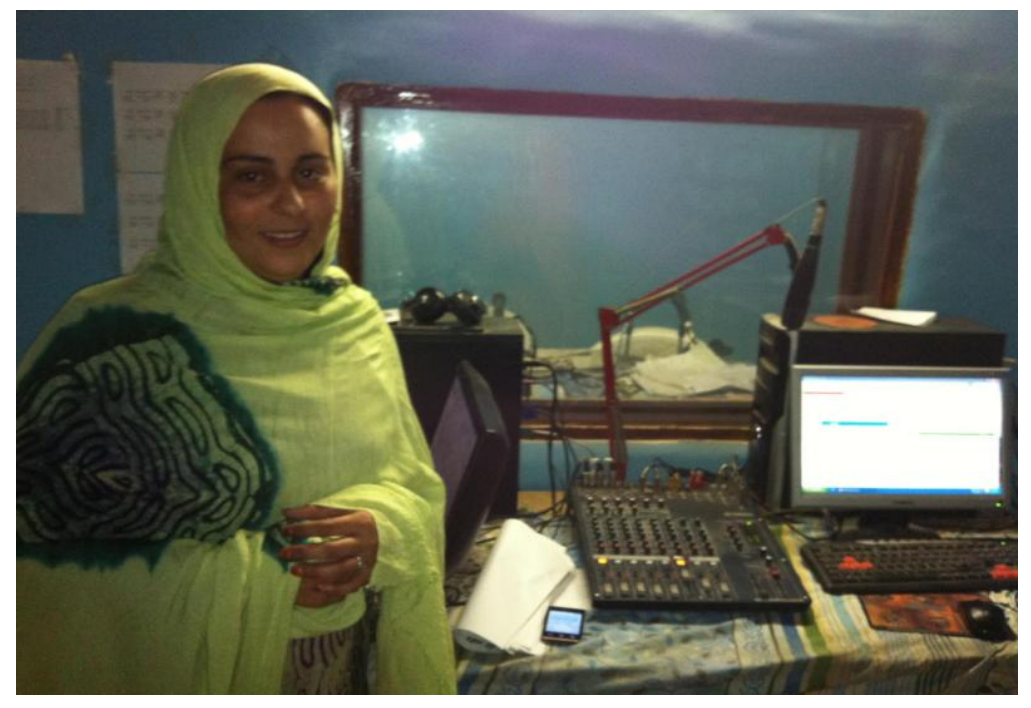

Figure 2. Radio station

They feel and are empowered. These are women who created their country's infrastructure on their own 38 years ago. They organized daily life in refugee camps. They occupy $75 \%$ of the jobs in education, $85 \%$ in public administration, and $75 \%$ in health care. They actively participate in politics. It is not uncommon to see women serving as police officers, teachers, doctors, etc. It is a phenomenon which is not often seen in Arab countries. They are involved in all facets of social and public life. Saharawi women are point of reference and role models for other African women.

They began and currently operate libraries, preschools, primary and secondary schools, and schools for children with special needs. They are educated either in formal or informal settings. The learned ones teach those that had no chance to go to school or study abroad. The governments of other countries such as Algeria, Cuba and Venezuela sponsor scholarships to young Saharawi women to study at universities. 


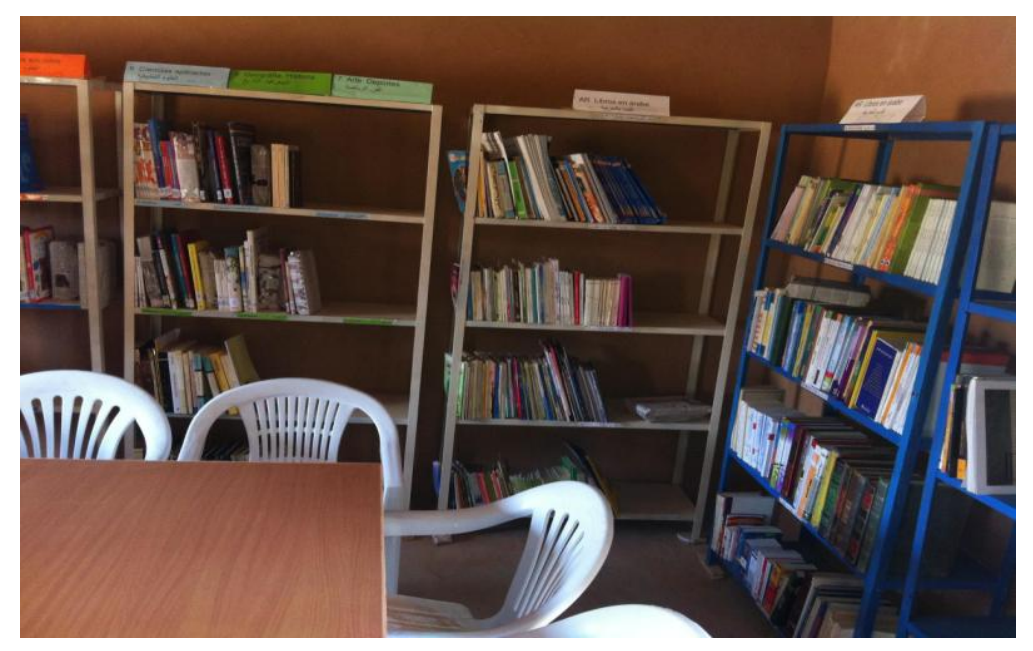

Figure 3. A Library in the middle of a desert

In the refugee camps, there are women's centers where they can receive computer and English classes, participate in sewing and carpet making workshops, publish magazines and traditional Saharawi poetry, as well as write poetry. They educate other women on health related health issues. They coordinate microloans and cooperative businesses. As is evident, they are very enterprising, even though they have to live in extremely difficult conditions.

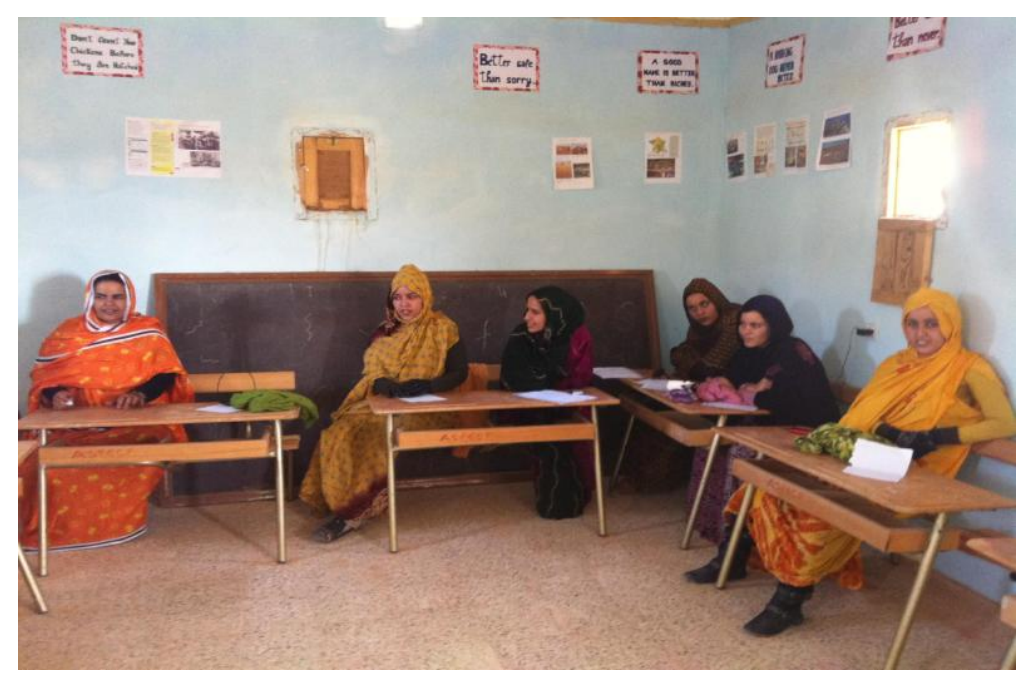

Figure 4. Classes/Workshops for women

They have begun an organization called the National Union of Saharawi Women whose main objective is to spread the cause of Saharawi people. Saharawi women were able to shatter the stereotype of Muslim and Arab women which exists in the Western World. Saharawi women are culturally different than those from other Muslim and Arab countries because in the Saharawi society, women have always been esteemed. Saharawi women are very patient, dignified, and willing to sacrifice themselves for the greater good. They are open and tolerant; 


\section{Mll Macrothink}

however, they are not submissive. The men had no choice but to accept this situation upon their return from the war, and many men currently live abroad.

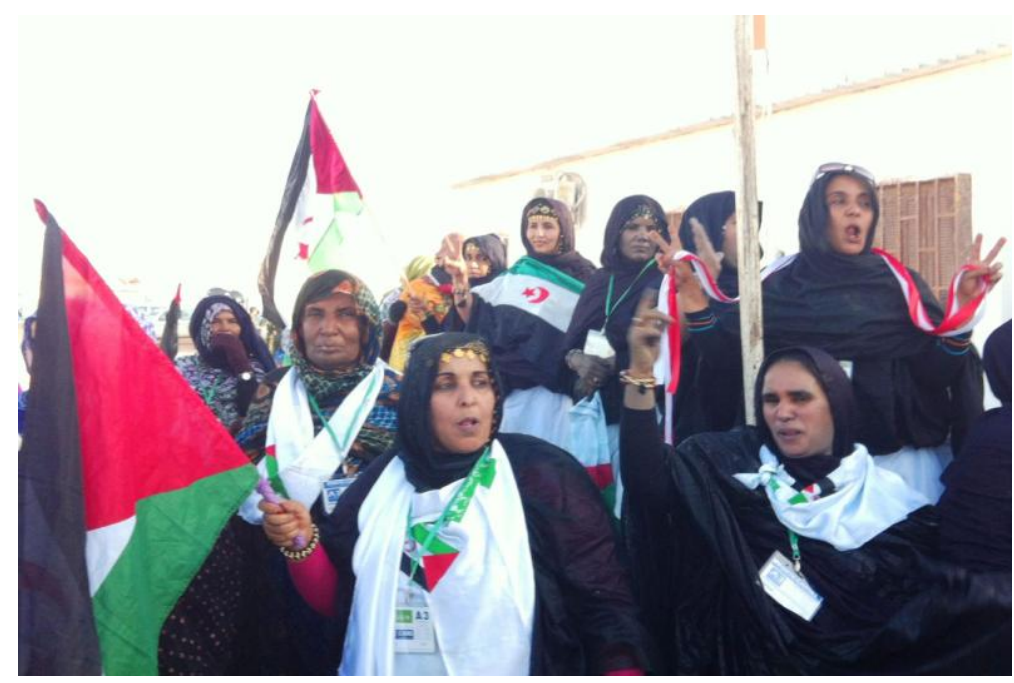

Figure 5. Peaceful protests of Saharawi women

Saharawi women have achieved a level of equality and empowerment unheard of in other Arab countries. They are a pillar of the non-violent Saharawi revolution and fight for the independence and self-determination of Saharawi people. The non-violence resistance consists of struggling for self-determination through a free and fair referendum, informing and denouncing the violence of the Moroccan State against peaceful Saharawi people, denouncing both the illegal exploitation of natural resources in Western Sahara territory as well as the placement land mines in the wall that divides the Sahara.

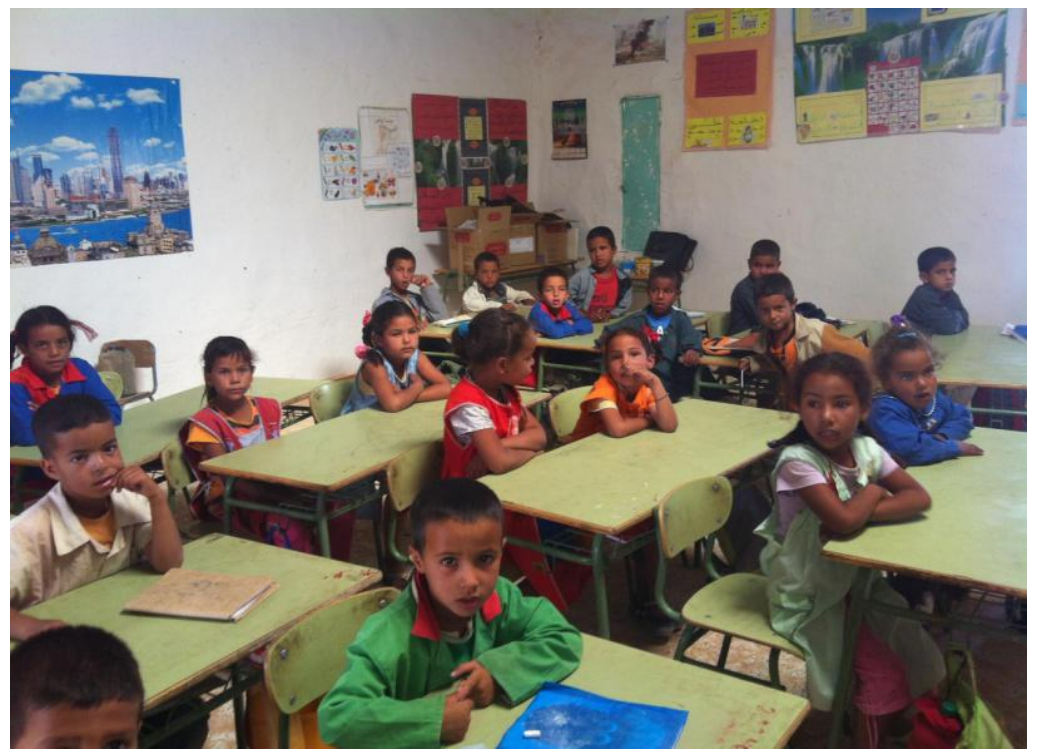

Figure 6. A school in Sahrawi refugee camp 


\section{Conclusion}

Saharawi women provide an excellent example for their children and transmit the values of peace, non-violent resistance, and not despairing in the face of difficult circumstances. They teach their children to look for peaceful resolutions. The Saharawi people do not live in despair and are not resigned. They keep fighting. Nevertheless, their resistance is non-violent in nature. Thanks to Saharawi women, young people are willing to participate in this non-violent struggle. Saharawi women educate a society of the future in democratic values, thereby preparing them for the eventual establishment of a nation that upholds the values of freedom and civil rights in which the Saharawi want to live.

In the Western Sahara territory occupied by Morocco, life is much more difficult due to continued cruel repression, kidnappings, and detentions as punishment for protesting in favor of autonomy for the Saharawi nation. They live in unbearable political, economic, and social conditions. Women and men are tortured, assaulted, insulted, kidnapped, raped, detained, exiled and discriminated against. Despite all of these atrocities against human rights they continue fighting for self-determination through a free and fair referendum.

Therefore, in order to help the Saharawi people it is necessary to break the wall of silence and make their fight more visible. The human rights violations must be openly denounced and the right to self-determination of Western Sahara as one of the 16 non-autonomous territories on the UN agenda and the last colony in Africa, must be defended.

\section{References}

Almario Parra, A. P. (2012). Análisis de la actuación de Naciones Unidas (ONU) en el proceso de paz entre la República Árabe Saharaui Democrática (RASD) y Marruecos en el marco del conflicto del Sahara Occidental. Periodo 1991-2010. Retrieved from http://repository.urosario.edu.co/bitstream/handle/10336/2949/1020742354-2012.pdf?sequen ce $=1$

Arts, K., \& Leite, P. P. (Eds.). (2007). International law and the question of Western Sahara. International Platform of Jurists for East Timor (IPJET).

Bachir, Senia (2008). Las mujeres saharauis y su lucha por la independencia. Global Affairs, No 8, pp. 8-11. Retrieved from http://paperroom.ipsa.org/papers/paper_33993.pdf

Barreñada, I. (2013). Asociacionismo y cuestión nacional en el Sahara Occidental. Revista de Estudios Internacionales Mediterráneos, (13). Retrieved from https://revistas.uam.es/ind ex.php/reim/article/view/888

Belloso, M. L. (2016). Migration And Vulnerability: Challenges, Implications And Difficulties Faced By The Sahrawi Migrant Population. The Age of Human Rights Journal, (7), 29-49. https://doi.org/10.17561/tahrj.n7.8

Beristain, C. M., \& González Hidalgo, E. (2012). El Oasis de la memoria. Memoria histórica y violaciones de Derechos Humanos en el Sáhara Occidental [The oasis of memory. Historical memory and human rights violations in the Western Sahara]. Bilbao, Spain: Hegoa. Retrieved 
from http://www.embajadasaharauimexico.org/wp-content/uploads/2016/01/El_Oasis_de_la _Memoria_RESUMEN.pdf

Contreras, D. (2007). Marruecos y la cuestión saharaui. Estudios Internacionales de la Complutense, 9(1), 51-71.

Darbouche, H., \& Zoubir, Y. H. (2008). Conflicting international policies and the Western Sahara stalemate. The International Spectator, 43(1), 91-105. http://dx.doi.org/10.1080/03 932720701880049

Darby, J., \& Mac Ginty, R. (2000). The management of peace processes, Ethnic and intercommunity conflict series.

El Mohtar, Jadiyetu. Personal interview. 16 September. 2013

Gascón, M. L. G., Fuentes, C. C., \& Seisdedos, S. R. Gender and armed conflict: the case of Sahrawi women. Retrieved from http://paperroom.ipsa.org/papers/paper_33993.pdf

Higgs, J., \& Ryan, C. (2015). Leaders in the desert: The Sahrawi women of Western Sahara. Retrieved from https://ir.canterbury.ac.nz/handle/10092/11184

Isidoros, K. (2017). Unveiling the Colonial Gaze: Sahrāwī Women in Nascent Nation-state Formation in the Western Sahara. Interventions, 19(4), 487-506. http://dx.doi.org/10.1080 /1369801X.2016.1277152

Juliano, D. (1998). La causa saharaui y las mujeres:" siempre hemos sido muy libres" (Vol. 16). Icaria Editorial.

Landeros-Casillas, M. I. (2016). Photography as an Intermediary in an Informal Artistic Education Project that Portrayed the Life of Sahrawi women. Revista Electrónica Educare, 20(2), 256-270. http://dx.doi.org/10.15359/ree.20-2.13

Lemarchand, P. (2000). Atlas de África. Acento.

Lippert, A. (1992). Sahrawi women in the liberation struggle of the Sahrawi people. Signs: Journal of Women in Culture and Society, 17(3), 636-651. http://dx.doi.org/10.1086/494752

Martín Lozano, Paz. "Visit to Refugee Camps, Radio Station.” 2013. JPEG file.

Martín Lozano, Paz. "Visit to Refugee Camps. A School in a Saharawi Refugee Camp.” 2013. JPEG file.

Martín Lozano, Paz. "Visit to Refugee Camps. Classes/Workshops for Women.” 2013. JPEG file.

Martín Lozano, Paz. "Visit to Refugee Camps. Library in the Middle of a Desert." 2013. JPEG file.

Martín Lozano, Paz. "Visit to Refugee Camps. Sahrawi Refugee Camps" 2013. JPEG file.

Martín Lozano, Paz. Personal interview. 22 July. 2013 
Martín, R. M., Justo, J. C. G., Sánchez, D. G., \& Morillo, M. J. R. (2016). Una visita a los campamentos de refugiados y refugiadas saharauis en Tindouf (Argelia): derecho, política y capital en los cuerpos. Revista Internacional de Pensamiento Político, 6, 495-510. Retrieved from https://www.upo.es/revistas/index.php/ripp/article/view/1885

Mera Miyares, Á. (2007). El Sáhara Occidental: ¿un conflicto olvidado. Sàhara Occidental. Sèrie Conflictes Oblidats. Barcelona: Institut de Drets Humans de Catalunya.

Mesa, M. (2006). La cooperación al desarrollo y la construcción de la paz (Vol. 142). Cáritas Española.

Milán, J. M. M. (2007). ESPAÑA EN EL SAHARA OCCIDENTAL: DE UNA CONOLIZACION TARDÍA A UNA DESCOLONIZACION INCONCLUSA, 1885-1975. In Anales de Historia Contemporánea (Vol. 23, No. 1, pp. 365-388). ISSN: 0212-65-59. Retrieved from http://revistas.um.es/analeshc/article/view/54471/52491

Neiberg, M. S. (2002). War and Gender: How Gender Shapes the War System and Vice Versa (review). Journal of Social History, 36(2), 504-506. https://doi.org/10.1353/jsh.2003.0029

Polo Lázaro, C. J. (2012). Resistencias cotidianas de las refugiadas saharauis. Vieitez Cerdeño, Soledad; Rodríguez Medela, Juan; Marín Sánchez, Isabel, coordinadores. Percepción del desarrollo dentro y fuera del continente africano. Granada: Universidad de Granada, 111-134.

Santiago, A. P., \& Domenech, J. P. (2013). Mujeres saharauis: un ejemplo de lucha y dignidad. CUADERNOS KÓRE, (7), 183-200. ISSN: 1889-9285. Retrieved from https://e-revistas.uc3m.es/index.php/CK/article/view/1698/773

Shelley, T. (2004). Endgame in the Western Sahara: what future for Africa's last colony?. Zed Books.

Trasasmontes, V. (2011). Los Campamentos de refugiados saharauis en Tinduf: una aproximación desde la economía/The Sahraoui Refugee Camps in Tindouf: An Economic Analysis. Revista de economía mundial, 29. Retrieved from http://hdl.handle.net/10272/5544

Varga, M. S. (2012). Una fuerza transnacional: los saharahuis en España. Historia Actual Online, (29), 117-124. Retrieved form http://www.historia-actual.org/Publicaciones /index.php/haol/article/viewArticle/771

Villar, F. (1982). El proceso de autodeterminación del Sáhara (Vol. 5). F. Torres.

Villena, A. M., \& Cerdeño, S. V. (2014). La Sección Femenina en la «llamada de África»: Saharauis y guineanas en el declive del colonialismo español/The Women's Section in the «Call of Africa»: Saharan and Guinean Women at the Fall of Spanish Colonialism. Vegueta: Anuario de la Facultad de Geografía e Historia, (14). Retrieved from http://revistavegueta.ulpgc.es/ojs/index.php/revistavegueta/article/view/275/525

Western Sahara: Country Reports on Human Rights Practices (2007) U.S. Department of State. Retrieved from http://www.state.gov/g/drl/rls/hrrpt/2007/102555.htm 


\section{Macrothink}

Issues in Social Science

ISSN 2329-521X 2017, Vol. 5, No. 2

Wilson, A. (2017). "For Us, Parliament Is a Tool for Liberation": Elections as an Opportunity for a Transterritorial Sahrawi Population. In Global, Regional and Local Dimensions of Western Sahara's Protracted Decolonization (pp. 313-331). Palgrave Macmillan US. http://dx.doi.org/10.1057/978-1-349-95035-5_15

Wolff, S. (2015). Migration and Refugees in the Mediterranean: Rethinking Geopolitical Constraints, Western-centric Policies and Mobility's Precariousness. Mediterranean Politics, 20(3), 439-444. http://dx.doi.org/10.1080/13629395.2015.1087106

Zunes, S., \& Mundy, J. (2010). Western Sahara: War, nationalism, and conflict irresolution. Syracuse University Press. 